(3)

Volume 14, 2019

\title{
REINFORCING INNOVATION THROUGH KNOWLEDGE MANAGEMENT: MEDIATING ROLE OF ORgaNiZATIONAL LEARNING
}

Abed Al-Fatah Karasneh Business Department, Yarmouk University, akarasneh@yu.edu.jo Irbid, Jordan

\begin{abstract}
Aim/Purpose The purpose of this study is to investigate the relationship between knowledge management $(\mathrm{KM})$ and organizational innovation $(\mathrm{OI})$. It also enriches our understanding of the mediating effect of organizational learning (OL) in this relationship.

Background KM's relationship with OL and OI has been tackled extensively in developed countries' literature. Nowadays, the challenges of developing countries lie in the process of knowledge application. This study attempts to develop a new managerial knowledgeable tool and present a theoretical model and empirical analysis of the relationship between KM and innovation in Jordan, a developing country. To the knowledge of the author, no attempt has been taken to investigate this relationship in any Jordanian sector.
\end{abstract}

Methodology The sample of this study consists of 457 managers representing strategic, tacti$\mathrm{cal}$, and operational levels randomly selected from 56 manufacturing companies in Jordan. A questionnaire-based survey has been developed based on KM, OL and OI literature to collect data. A structural equation modeling (SEM) approach was applied to investigate the proposed research model.

Contribution This study contributes to the literature in different ways. First, it asserts that OL assists in improving OI in manufacturing organization of developing countries. Second, it highlights the substantial benefits of applying KM, OL and OI in manufacturing companies in Jordan. Furthermore, it enhances the relationship between KM and innovativeness' literature by providing empirical evidence, suggesting that OL is as important as KM to advance organizational innovation. Most importantly, it identifies the problem of a developing economy which is not promoting OL or taking care of it as much as they attended to KM in their organizational practices.

Accepting Editor Christine Nya-Ling TAN | Received: June 30, 2019 | Revised: August 15, August 272019 | Accepted: September 19, 2019.

Cite as: Karasneh, A. A-F. (2019). Reinforcing innovation through knowledge management: Mediating role of organizational learning. Interdisciplinary Journal of Information, Knowledge, and Management, 14, 235-252. https://doi.org/10.28945/4427

(CC BY-NC 4.0) This article is licensed to you under a Creative Commons Attribution-NonCommercial 4.0 International License. When you copy and redistribute this paper in full or in part, you need to provide proper attribution to it to ensure that others can later locate this work (and to ensure that others do not accuse you of plagiarism). You may (and we encourage you to) adapt, remix, transform, and build upon the material for any non-commercial purposes. This license does not permit you to use this material for commercial purposes. 
Findings

Recommendations for Practitioners

Recommendations for Researchers

Impact on Society

Future Research

Keywords
Study findings indicate that the relationship between KM and OI is significantly positive. Results also reveal that the relationship between KM and organizational learning is significantly positive. Empirical results emerging from this study indicate that there is partial mediation to support the relationship between OL and OI.

This study suggests that managers ought to recognize that organizational learning is equally important to KM. This entails that OL should be utilized within organizations to achieve organizational innovation. Moreover, managers ought to comprehend their importance and encourage their employees to adopt knowledge from various sources; which, if implemented correctly, will enhance the OL environment.

The research model can be used or applied in different manufacturing and service sectors across the globe. The findings of the current study can serve as a foundation to perform different studies to understand KM processes and recognize its antecedence.

This study presents insights on how to apply KM, OL and OI methodologies in Jordanian manufacturing companies to achieve a competitive advantage; hence, positively influencing society.

Future research may include conducting a similar study in the context of developed countries and developing countries which allows for comparison. Also, future research may examine the impact of $\mathrm{KM}$ on organizational performance applying both OL and OI as mediating variables.

knowledge management, organizational learning, organizational innovation, Jordanian manufacturing companies

\section{INTRODUCTION}

Competitive pressures have inspired organizations to re-assess their strategies and develop their competencies. Knowledge management $(\mathrm{KM})$ is considered one of the modern management disciplines identified by organizations as a critical factor affecting organizations' endeavors in products and services development (Baxter, Roy, Doultsinou, Gao, \& Kalta, 2009). KM emerged to emphasize an organization's ability to encourage individuals to learn and innovate new knowledge and ideas in order to apply them in decision making and to sustain a competitive advantage (Karasneh \& AlZoubi, 2018). The emergence of knowledge as invaluable assets and an essential source of a firm's sustainable competitive advantage (Nonaka, Toyama, \& Konno, 2000) has inspired researchers and initiatives to develop a critical relationship between $\mathrm{KM}$ and organizational learning (Bagheri, Hamidizadeh, \& Sabbagh, 2015; Brockman \& Morgan, 2003; Jiménez-Jiménez \& Sanz-Valle, 2011; Liao \& Wu, 2010; Ngah, Tai, \& Bontis, 2016; Thomas, Sussman, \& Henderson, 2001) as well as KM and organizational innovation (e.g., Bagheri et al., 2015; Baker \& Sinkula, 2002; Darroch, 2005; Darroch \& McNaugton, 2003; Du Plessis, 2007; Goh, 2005; Jiménez-Jiménez \& Sanz-Valle, 2011; Massa \& Testa, 2004; Tamer Cavusgil, Calantone, \& Zhao, 2003).

The literature of developed countries has extensively researched KM's relationship with organizational learning (OL) and organizational innovation (OI). Bagheri, et al. (2015) indicate that knowledge is considered an important asset in developed countries which can evoke change and innovation in organizations. Nowadays, the challenges of developing countries lie in the process of knowledge application. Jordan faces certain challenges and obstacles for evoking knowledge assets for a number of reasons. First, Jordanian industries are not capable of satisfying customers nor competing with international industries. This can be seen through the industry recession and the prosperity of international industries. Second, Jordan is a developing country and manufacturing companies 
still applying traditional less innovative procedures. Although these challenges are present, compared to countries in the region, Jordan's human capital is a resource of strength that has the capabilities of innovation for progression. This can be seen through the extensive enhancement of economic status that is being applied.

This study attempts to develop a managerial tool based on KM that touches the essence of the contemporary work environment for Jordanian industry. It aims to present a theoretical model and empirical analysis of the relationship between $\mathrm{KM}$ and innovation. It also enriches our understanding of the mediating effect of OL in this relationship. Moreover, this study may shape the thinking abilities of Jordanian industry managers in particular and employees in Jordanian organizations, in general, to gain knowledge and aid their organizations into competing in the global market. To the knowledge of the author, no attempt has been taken to investigate this relationship in any Jordanian sector.

The next section highlights the literature review and develops the hypotheses. Then the author presents a description of the research methodology adopted in this paper. Followed by an analysis of the findings. The subsequent section discusses the empirical analysis of results. Finally, the paper provides contributions, conclusions and recommendations for future research, and theoretical and managerial implications.

\section{LITERATURE REVIEW AND HYPOTHESES}

\section{KNOWLEDGE MANAGEMENT}

Literature conceptualizes KM and provides distinct processes that enhance organizations' abilities to sustain a competitive advantage (Nonaka \& Von Krogh, 2009). Building on Nonaka's work, authors (e.g., Ahn \& Chang, 2004; Andone, 2009; Bryant, 2005; González, Giachetti, \& Ramirez, 2005; Hsu, Lawson \& Liang, 2007; Huang, Chen \& Yieh, 2007; Karasneh, 2002; Karasneh \& Al-Khalili, 2009; Kuah, Wong \& Wong, 2012; Lopez-Nicolas \& Soto-Acosta, 2010; Patton, 2001; Uotila, 2017 ) indicate that KM consists of different processes and activities. Karasneh (2002) asserts that KM consists of five main processes (i.e., creation, adoption, adaptation, embodiment and evaluation). He argues that as knowledge is required by organizations, it should be either internally created or externally adopted from best-practice organizations. Subsequently, knowledge either created or adopted ought to be adapted in the specific context of an organization. The embodiment process distinguishes the ability of the organisation to codify, distribute, transfer, and translate the adapted knowledge into practice. The knowledge evaluation process is necessary for assessing all forms of knowledge in the application within organizations. Bryant (2005) concludes that the presence of high levels of knowledge creation leads to higher perceived levels of peer mentoring. Dul, Ceylan, and Jaspers (2011) study the impact of the physical work environment on workers' creativity in comparison with the effects of personality innovation and the socio-organizational work environment. Results support HR practices that put emphasis on the individual, socio-organizational work environment, and physical work environment to elevate workers' creativity.

The success of KM depends on the ability of organizations to promote a critical synthesis between KM processes capabilities and KM infrastructure capabilities. Bharadwaj, Chauhan, and Raman (2015) investigate the impact of KM capabilities (i.e., creation/acquisition, storage, dissemination, and application) and infrastructure capabilities on organizational knowledge effectiveness. They conclude that organizations have started realizing the importance of managing knowledge as a strategic asset. Svetina and Prodan (2008) investigate the extent to which different knowledge sources contribute to the firms' innovation performance. They conclude that internal sources have the most important influence on firms' innovative performance. They also conclude that in-house learning is not sufficient for generating innovation and that firms need to supplement internal knowledge with knowledge acquired outside the firm. McAdam (2000) conclude that the proper application of knowledge embodiment in an innovative manner is critical for an organization's success as well as the competitiveness. Karasneh \& Alkalili (2009) investigate the actual practice of KM activities in the 
Ministry of Education in Jordan. They conclude that the practicing level of (knowledge creation, knowledge adoption) is high while the practicing level for (knowledge adaptation and knowledge embodiment) is medium.

\section{KM AND ORGANIZATIONAL INNOVATION}

$\mathrm{KM}$ literature conceptualizes innovation as a critical factor for organizations to create value and maintain a competitive advantage in a highly complex and dynamic environment (Bagheri et al., 2015; Bose, 2004). Nonaka and Von Krogh (2009) indicate that the theory of organizational knowledge creation targets developing a comprehensive view of knowledge that could recognize organizational creativity, learning, innovation, and change. Nonaka and Takeuchi (1995) argue that the dissemination of innovation depends on the capability of an organization to produce, use, and disseminate knowledge. KM practices encourage the generation of new knowledge and organizational learning which is fundamental for achieving advantages based on innovation (Zack, McKeen, \& Singh, 2009). Organizational innovation is the process in which new knowledge is adopted, adapted, disseminated and integrated to generate new knowledge. The integration of KM and organizational innovation leads to sustainable competitive advantage (Bashir \& Farooq, 2019; Gloet \& Terziovski 2004).

knowledge is the starting point for the development of innovations and can be generated either externally or internally. Ferraris, Santoro, and Dezi, (2017) argue that firms which develop and possess superior knowledge management capabilities have the ability to better manage external knowledge and combine it with the internal one. Cantner, Joel, and Schmidt (2011) conclude that firms that apply KM are more successful with product and market innovations compared to firms that do not apply KM. Kiessling, Richey, Meng, and Dabic (2009) conclude that KM practices contribute significantly to product progress, employee innovation and firm innovation. Palacios, Gil, and Garrigos (2009) identify several KM abilities that are essential for innovation development, such as skills development, knowledge flow management, acquisition of internal knowledge, transfer, dissemination and internal application of accumulated knowledge and increase in the variety of the organizational memory. Darroch (2005) asserts that the KM process would positively affect organizational innovation. Thus, the relationship between KM and innovation is closely related. Therefore, the following hypothesis is proposed:

H1: Knowledge management positively affects organizational innovation.

\section{KM AND ORGANIZATIONAL LEARNING}

Organizational learning has been widely identified in the literature. Jiménez-Jiménez and Sanz-Valle (2011) indicate that organizations develop new knowledge from common experiences through OL process. The development of new knowledge influences behaviors and improves the firm's capabilities. They argued that OL processes include knowledge acquisition, knowledge distribution, knowledge interpretation, and organization memory. Garvin, Edmondson, and Gino (2008) state that organizational learning is "the only sustainable competitive advantage" for organizations. Senge (1992) defines the learning organization as the comprising of a group of people continue to enhance their capacity to create what they aspire. OL is a crucial concept for organizations to sustain and achieve a competitive advantage and a nucleus in organizational innovation (Bukowitz \& Williams, 1999; Liao \& Wu, 2010; Nonaka \& Von Krogh, 2009; Therin, 2003; Wang \& Xu, 2018). JerezGomez, Cespedes-Lorente, and Valle-Cabrera (2005) state that knowledge and, more specifically, its acquisition or creation, along with its dissemination and integration within the organization, become a key strategic resource to OL.

Liu, Zhou, and Gao (2008) investigate the inter-relationships among organizational learning, knowledge transfer and dynamic capabilities. They conclude that organizational learning has a direct positive impact on knowledge transfer but no direct positive impact on organizational dynamic capabilities. Lin \& Lee (2005) examine the impact of organizational learning factors and knowledge man- 
agement processes. They conclude that organizational learning factors and knowledge management processes are closely related to the level of e-business systems adoption. Yang (2007) investigate the extent to which knowledge sharing and organizational learning affect organizational effectiveness. He concludes that knowledge sharing facilitates the transformation of collective individual knowledge to organizational knowledge. Furthermore, this would result in the advancement of organizational learning and eventually, the enrichment of organizational effectiveness.

Attia and Essam Eldin (2018) examine the effect of KM capabilities on organizational learning (OL) and supply chain management practices (SCMPs). They conclude that SCMP and OL are positively affected by KMC. Walczak (2008) examine international studies of knowledge management (KM) and organizational learning (OL). He concludes that there is a need to increase research that examines $\mathrm{KM}$ and OL existing in different and multiple countries. Additionally, cultural factors should be included in KM and OL research analysis. Actually, most of the theoretical and empirical work suggests a positive relationship between KM and OL. Therefore, the following hypothesis is proposed:

H2: Knowledge management positively affects organizational learning.

\section{ORGANIZATIONAL LEARNING AND INNOVATION}

Organizational learning and innovation have been identified by many scholars (e.g., Jiménez-Jiménez \& Sanz-Valle, 2011; Nonaka \& Takeuchi, 1995; Sørensen \& Stuart, 2000; Stata, 1989). Karasneh and Al-zoubi (2018) indicate that individuals utilize existing knowledge and share it within the organization to create new knowledge. The utilization of knowledge depends on the capacity of individuals to understand, learn, apply, and innovate new knowledge. Jiménez-Jiménez and Sanz-Valle (2011) state organizational learning allows the development, acquisition, transformation and exploitation of new knowledge that enhances organizational innovation. The relationship between organizational learning and innovation has been conceptually recognized, there is still a dearth in empirical evidence (Darroch \& McNaugton, 2003; Jiménez-Jiménez \& Sanz-Valle, 2011). For example, Salehi and Naseri (2018) conclude that organizational learning capability has a significant impact on organizational innovation in the Iranian food industry. Jain and Moreno (2015) conclude that organizational learning factors were found to be the positive predictors of KM practices and firm's performance. Kiziloglu (2015) concludes that there is a positive relationship between organizational learning and innovation in the Turkish banking sector. Hurley and Hult (1998) conclude that a high level of innovativeness is associated with a learning culture. Generally, most current literature finds a positive relationship between OL and innovation. Therefore, the following hypothesis is proposed:

H3: Organizational learning positively influences organizational innovation.

\section{MEDIATOR BETWEEN KM AND OI}

Current literature identifies the role of OL as a mediating variable between different perspectives. For example, Imran, Ilyas, and Fatima (2017) utilize OL to mediate the relationship between organizational performance and KM capabilities. Raj \& Srivastava (2013) examine the mediating role of OL on organizational culture, HRM Practices and Innovativeness. Kalmuk and Acar (2015) use OL to mediate the relationship between Innovation and Firm's Performance. Real, Roldán, and Leal (2014) study the mediating role of OL on the influence of entrepreneurial orientation and learning orientation. Wang and $\mathrm{Xu}$ (2018) perceive OL to mediate the relationship between Customer knowledge management and radical innovation. Vieira (2013) indicates that OL has emerged as an organizational capability to face the change forthcoming from the turbulent and dynamic environment. Previous studies rarely investigated the mediating role of OL between KM and OI. For instance, Nouri, Ghorbani and Soltani (2017) investigate the influence of KM on organizational innovation concerning the mediating role of organizational learning. They conclude that KM has an insignificant impact on organizational innovation but has a significant and positive impact on organizational learning. Jerez-Gomez, et al. (2005) state that "knowledge and, more specifically, its acquisition or creation, 
along with its dissemination and integration within the organization, become a key strategic resource to organizational learning". According to (Crossan, Lane, and White,1999; Huber, 1991; Jerez-

Gomez et al., 2005) Organizational learning is seen as a dynamic process based on knowledge, which implies moving among the different levels of action, going from the individual to the group level, and then to the organizational level and back again. Similarly, Allameh, Rezaei, and Bagheri (2014) concluded that organizational learning functions as a significant mediator between critical success factors of $\mathrm{KM}$ and organizational innovation.

Liao and Wu, (2010) investigate the effect of the knowledge creation process on organizational innovation and the mediating effect of organizational learning. They conclude that organizational learning is the mediating variable between KM and organizational innovation. Consequently, KM is an important input, and organizational learning is a key process. Finally, organizational innovation is a critical output. Thus, by extending the current literature, the following hypothesis is proposed:

H4: Organizational learning moderates the relationship between knowledge management and organizational innovation.

The interrelationships among the four postulated hypotheses shape the research conceptual model (Figure 1).

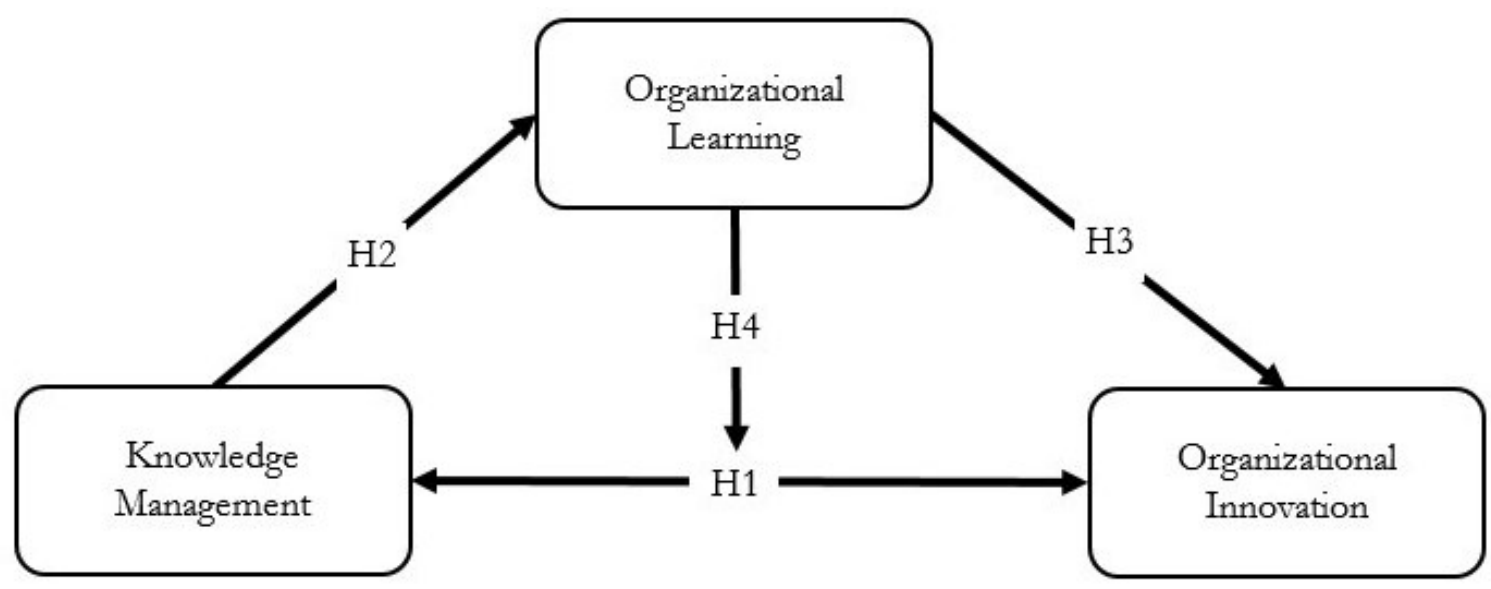

Figure 1: Conceptual Model

\section{RESEARCH METHODOLOGY}

\section{SAMPLE}

Data was collected from the manufacturing sector which is thought to be an effective medium for KM applications and practices (Birasnav \& Rangnekar, 2010; Corfield, Paton, \& Little, 2013; Karasneh \& Al-Zoubi, 2018). The community of this study consists of managers in the strategic, tacti$\mathrm{cal}$, and operational management levels who were randomly selected from manufacturing companies in Amman, Jordan. Fifty-six industrial companies (i.e., Chemical, medical, food, petrochemicals, Mining, pharmaceutical, steel and iron, Aluminum, Cable) listed in Amman Stoch Exchange were selected.

\section{INSTRUMENTS}

A questionnaire for data collection was developed based on previous work (Appendix) with some modifications to fit the nature and need of the study (Table 1). Knowledge management dimension is measured by (16) items based on four variables suggested by (Karasneh, 2002). These variables are knowledge creation, knowledge adoption, knowledge adaptation, and knowledge embodiment. The 
measurement items of these variables are synthesized and developed based on previous literature. Organizational learning dimension is measured by (5) items suggested by (Ju, Li, \& Lee, 2006). Organizational innovation is measured through (20) items based on five variables adopted by (Wang \& Ahmed, 2004). These variables are knowledge behavior innovation, product innovation, process innovation, market innovation, and strategic innovation.

The first draft of the questionnaire was pilot tested for authenticity (Recker, 2011) on (20) managerial staff working in various industries and attending a KM workshop with the author. The mangers of those companies provided the author with the e-mails of their managerial staff. The final authorized version of the questionnaire was e-mailed to the managers.

Table 1: KM Measurement item references

\begin{tabular}{|l|c|l|}
\hline Variables & $\begin{array}{l}\text { No. of } \\
\text { Items }\end{array}$ & References \\
\hline Knowledge creation & 4 & $\begin{array}{l}\text { (Ahn \& Chang, 2004; Bryant, 2005; Huang et al., 2007; Kuah et al., } \\
\text { 2012). }\end{array}$ \\
\hline Knowledge adoption & 4 & $\begin{array}{l}\text { (González et al., 2005; Hsu et al., 2007; Lopez-Nicolas \& Soto- } \\
\text { Acosta, 2010; Patton, 2001). }\end{array}$ \\
\hline Knowledge adaptation & 4 & (Karasneh, 2002; Karasneh \& Al-Khalili, 2009; Uotila, 2017). \\
\hline Knowledge embodiment & 4 & $\begin{array}{l}\text { (Andone, 2009; Karasneh, 2002; Karasneh \& Al-Khalili, 2009; } \\
\text { Kuah et al., 2012). }\end{array}$ \\
\hline Organizational Learning & 5 & Ju et al., 2006 \\
\hline Organizational Innovation & 20 & Wang \& Ahmed, 2004 \\
\hline
\end{tabular}

\section{PROCEDURE}

A total of 666 questionnaires were distributed via email between December 2018 and January 2019. Follow up was carried out in two forms. First, email reminders for participants. Second, multiple WhatsApp messages to the surveyed companies' executives one week later to encourage their managers in different managerial levels for participation. 457 complete and valid questionnaires were returned with a response, return rate of 68.6 percent. Respondents were fit in terms of the desire to adopt knowledge and its antecedents to encourage employees to innovate, create and learn. The high respondent rate may be attributed to the determination of those executives attending the workshop with the author to diagnose their problem. Moreover, the chance of a non-response bias test was carried out between early and late respondents and results suggest that non-response bias is not significant.

\section{DATA ANALYSIS}

Statistical Package for Social Sciences (SPSS) program was used to analyze the questionnaire of participants to examine the demographic characteristics of the questionnaire items (i.e., 457). Among these participants, 70.5 percent were males, while 29.5 percent were females. The average age of respondents is 38.6 years. The analysis of targeted group is as follows: Team leaders ( 38.5 percent), Managers (23.6 percent); Chief officers (19.3 percent); Directors (15.1 percent); and Supervisors (3.5 percent). The average experience of respondents is 14.33 years. The minimum qualification of respondents is a bachelor's degree.

The statistical analysis reveals that KM dimension is significantly and positively correlated with OL and OI. Moreover, the correlation between KM and OL is (0.711), between KM and OI (0.671), and between OL and OI (0.728). This indicates an expected relationship between KM and OL and organizational innovation. Additionally, OL revealed a positive relationship with OI variables. The correlation among KM, OL and OI dimensions are statistically significant showing low indications of multicollinearity. Cronbach's coefficient alpha reliability estimates were utilized to measure the internal consistency of the questionnaire items. Cronbach's alpha reliability estimate for KM dimension is 
(0.83); for OL dimension is (0.86); and for OI dimension is (0.82). These estimates reveal that the scale is reliable.

\section{VALIDITY}

Confirmatory factor analysis (CFA) was carried out to test convergent validity for all the three dimensions separately. A five-point Likert scale was used to measure all items. The detailed description of CFA is as follows:

\section{Knowledge management (KM):}

This dimension is measured by 16 items. CFA results (Table 2) show that the proposed model did not fit the data well. Model improvement can be utilized by deleting some items based on exploratory factor analysis (Hair, Black, Babin, \& Anderson, 2014 p. 630). In fact, five items have been deleted. The fit measures of the revised four variables model are shown in (Table 2) and suggest that the scale is valid. The standardized factor loadings $(\Upsilon)$ of the four variables are $\Upsilon=0.74(\mathrm{p}<0.05), \Upsilon=$ $0.79(\mathrm{p}<0.01), \Upsilon=0.73(\mathrm{p}<0.05)$, and $\Upsilon=0.74(\mathrm{p}<0.05)$ respectively. The Cronbach's alpha coefficient $(\alpha)$ for the revised scale was 0.85 .

Table 2: CFA of knowledge Management four factors model

\begin{tabular}{|l|c|c|c|c|c|}
\hline Dimension & CMIN/df & p-value & RMSEA & GFI & CFI \\
\hline $\begin{array}{l}\text { KM four variables } \\
\text { model }\end{array}$ & 3.77 & 0.000 & 0.09 & 0.74 & 0.72 \\
\hline $\begin{array}{l}\text { KM four Variables } \\
\text { revised model }\end{array}$ & 2.12 & 0.08 & 0.05 & 0.97 & 0.97 \\
\hline
\end{tabular}

\section{Organizational Learning (OL):}

This dimension is measured by five items. Results of CFA (Table 3) show that the proposed model fit the data well. The standardized factor loadings $($ ) of the five variables are $0.73,0.70,0.72,0.70$, and 0.73 respectively. The Cronbach's alpha coefficient $(\alpha)$ for the scale was 0.86 .

Table 3: CFA of Organizational Learning model

\begin{tabular}{|l|c|c|c|c|c|}
\hline Dimension & CMIN/df & p-value & RMSEA & GFI & CFI \\
\hline $\begin{array}{l}\text { Organizational } \\
\text { Learning }\end{array}$ & 1.688 & 0.107 & 0.039 & 0.992 & 0.996 \\
\hline
\end{tabular}

\section{Organizational Innovation (OI):}

This dimension is measured by 16 items. CFA results (Table 4) show that the proposed model did not fit the data well. Model improvement can be utilized by deleting some items based on exploratory factor analysis (Hair et al, 2014 p. 630).

The fit measures of the revised five variables model are shown in Table (4) and suggest that the scale is valid. The standardized factor loadings $(\Upsilon)$ of the five variables are $\Upsilon=0.57(\mathrm{p}<0.05), \Upsilon=0.59$ $(\mathrm{p}<0.05), \Upsilon=0.85(\mathrm{p}<0.05), \Upsilon=0.81(\mathrm{p}<0.05)$, and $\Upsilon=0.55(\mathrm{p}<0.05)$ respectively. The Cronbach's alpha coefficient $(\alpha)$ for the revised scale was 0.86 .

Table 4: CFA Organizational Innovation five variables model

\begin{tabular}{|l|c|c|c|c|c|}
\hline Dimension & CMIN/df & p-value & RMSEA & GFI & CFI \\
\hline $\begin{array}{l}\text { Organizational Innovation five } \\
\text { variables model }\end{array}$ & 20.696 & 0.000 & 0.09 & 0.926 & 0.799 \\
\hline $\begin{array}{l}\text { Organizational Innovation five } \\
\text { Variables revised model }\end{array}$ & 1.524 & 0.206 & 0.034 & 0.996 & 0.998 \\
\hline
\end{tabular}




\section{STRUCTURAL MODEL}

Structural equation modeling (SEM) of AMOS (v-21) is carried out to test the model (Hair et al, 2014). Fit indices for the model are CMIN/df $=2.246, \mathrm{p}<0.000, \mathrm{RMSEA}=0.052$, GFI $=0.952$ and CFI $=0.958$ (Table 5). The fit model turned out to be satisfactory indicating that the interrelations are consistent with the given data.

Table 5: Fit indices for hypothesized model

\begin{tabular}{|c|c|c|c|c|c|}
\hline \multirow{2}{*}{ hypothesized model } & CMIN/df & p-value & RMSEA & GFI & CFI \\
\cline { 2 - 6 } & 2.246 & 0.000 & 0.052 & 0.952 & 0.958 \\
\hline
\end{tabular}

\section{Hypothesis testing}

To test the four postulated hypotheses, Path analysis estimates is utilized. A holistic study to the standardized parameter estimates indicates that the four hypotheses revealed a significant relationship and were as foreseen. The results of (Table 6) revealed that the relationship between knowledge management and organizational innovation is significantly and positively related to organizational innovation. The statistically significant parameter estimates $(\beta=0.52, \mathrm{p}<0.01)$ between KM and OI indicated support for H1. Moreover, the results of Table (6) provide enough support for hypothesis $\mathrm{H} 2$ and $\mathrm{H} 3$, Knowledge management is significantly and positively related to organizational learning, the path coefficient $(\beta=0.79, \mathrm{p}<0.01)$ between $\mathrm{KM}$ and OL, and the path coefficient $(\beta=0.37, \mathrm{p}<$ 0.01 ) between OL and OI. Figure 2 shows the factor loading and standardized path coefficients.

Finally, the mediation effect of OL between KM and OI (H4) is tested based on Baron's and Kenny's (1986) suggestions. According to them, the mediation is at its strongest when there is "full mediation" (i.e., when there is an indirect effect but no direct effect.) However, when there are both indirect and direct effects, they refer to it as "partial mediation". The results in (Table 7) of direct, indirect and total effects for each dimension reveal a significant path from KM to OL and from OL to OI. The importance of the indirect effect was utilized using the Sobel z-value (Sobel, 1982) and it was $6.75(\mathrm{p}<0.01)$. Therefore, regarding the current study, OL is a mediator between KM and OI. Yet, the mediation is only partial as both path coefficients are significant. Authors (e.g., Awang, 2015; Preacher \& Hayes, 2008; Raj \& Srivastava, 2016) indicate that when the coefficients of direct and indirect effects are significant, a partial mediation explains such a phenomenon. Thus, $\mathrm{H} 4$ is supported. This result is consistent with (Hsiao, Chang \& Chen, 2014; Raj \& Srivastava 2016).

Table 6: Standardized path coefficients for the model

\begin{tabular}{|l|c|c|c|c|c|c|}
\hline Hypotheses & Paths & Estimates & S.E. & C.R. & P-Value & Result \\
\hline H1 & OL<--- KM & 0.79 & 0.111 & 9.894 & $0.000 *$ & Supported \\
H2 & OI $<---~ K M$ & 0.52 & 0.070 & 4.721 & $0.000^{*}$ & Supported \\
H3 & OI <--- OL & 0.37 & 0.048 & 3.649 & $0.002 *$ & Supported \\
\hline *Significant at $p<0.01$.
\end{tabular}

Table 7: Direct and indirect relationship

\begin{tabular}{|l|c|c|c|c|c|c|}
\hline \multicolumn{9}{|c|}{ Endogenous } \\
\hline Dimension & \multicolumn{2}{|c|}{ Organizational learning } & \multicolumn{2}{c|}{ Organizational Innovativeness } \\
\hline Exogenous & Direct & Indirect & Total & Direct & Indirect & Total \\
\hline Knowledge Management & $0.79 *$ & $0.00 *$ & $0.79 *$ & $0.520^{*}$ & $0.190 *$ & $0.710^{*}$ \\
\hline Organizational learning & 0.00 & 0.00 & 0.00 & $0.37 *$ & 0.00 & $0.37 *$ \\
\hline Standardized path estimates are reported; ${ }^{*} \mathrm{p}<0.01$ \\
\hline
\end{tabular}




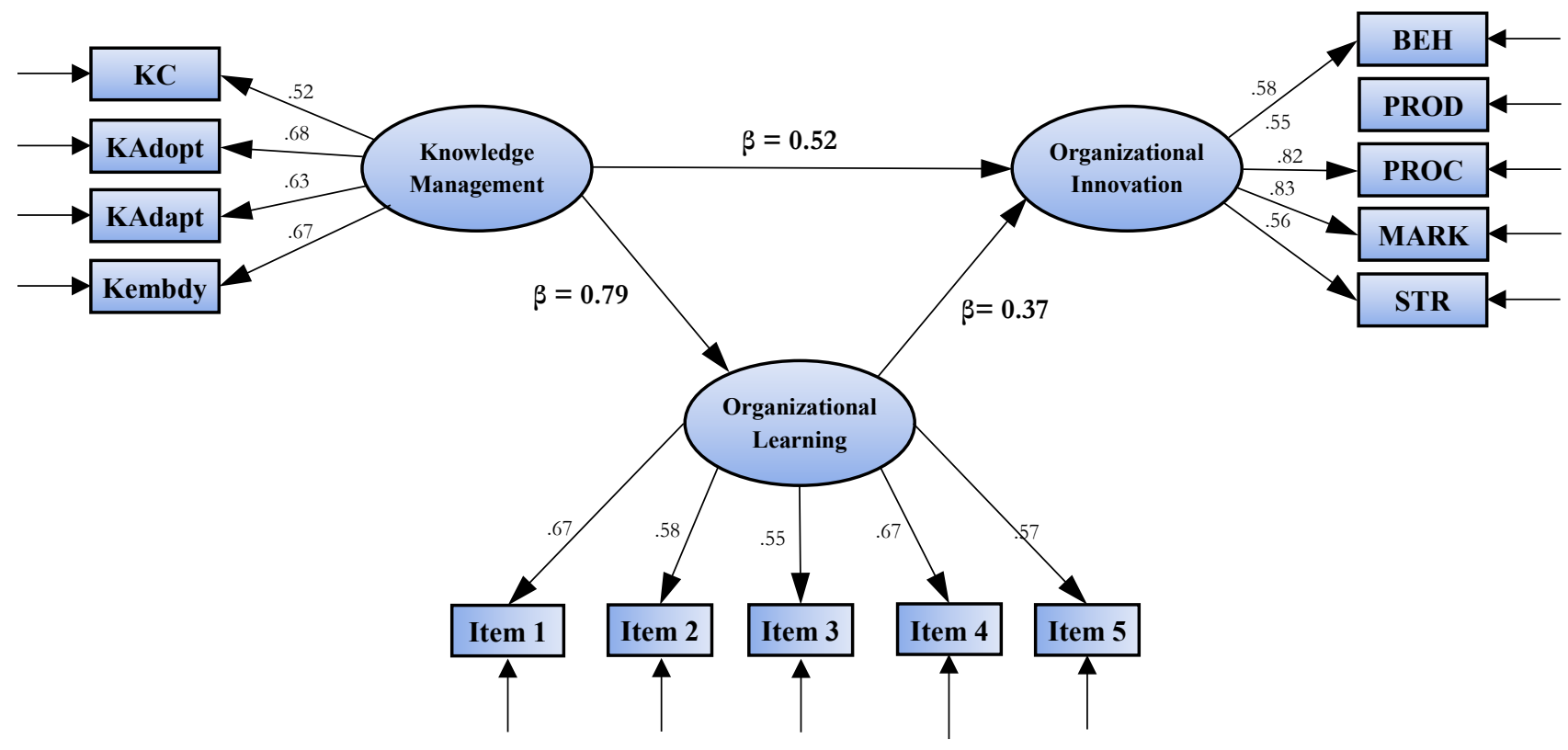

Figure 2: Path coefficients of the research model

\section{FINDINGS AND DISCUSSION}

Little is known about the interrelationships among knowledge management, organizational learning, and organizational innovation, especially in developing countries. The majority of work undertaken up to date tackling such an interrelation is mainly highlighted the domain of developed countries. This research investigates the mutual relations amongst knowledge management, organizational learning, and organizational innovation in a developing and promising economy. Study results and implications are discussed as follows:

First, study results reveal that the relationship between knowledge management and organizational innovation is significantly positive. This result is consistent with Jerez-Gomez et al. (2005), Nonaka \& Von Krogh (2009), Stanovcic, Pekovic, and Bouziri (2015), and Zack et al. (2009). Second, results also reveal that knowledge management and organizational learning are significantly positive. Many scholars have established critical and important relations between KM and OL. They assert that KM is a key strategic resource to organizational learning (Jerez-Gomez et al., 2005); OL is complementary to KM (King, 2009); therefore, OL has to do with embedding what has been learned into the fabric of the organization and is gradually absorbed within KM (Castaneda, Manrique, \& Cuellar, 2018).

Moreover, OL develops a strategic learning capability by linking learning with KM in and among organizations (Dimitriades, 2005).

Third, empirical results emerging from this study indicate that there is partial mediation to support the relationship between OL and OI. This result is consistent with (Hsiao et al., 2014; Raj \& Srivastava, 2016). These results suggest that surveyed organizations should focus on organizational learning and its process, in the same manner, to promote innovation in their organizations. The management's problem in the surveyed organizations may lie in the fact that managers exert their efforts to embrace KM leaving out OL component and its processes. The partial mediation of OL entails that organizations ought to develop certain means of improving their innovativeness. It is important to recall that KM consists of four dimensions (i.e., creation, adoption, adaptation, and embodiment). These dimensions ought to encourage managers to enhance learning and innovation. For example, the adoption of best practice knowledge may afford a valuable source of learning. The adaptation of adopted 
knowledge to organizational context ought to enhance the employee's ability to learn and hence innovate new ideas and knowledge. Knowledge embodiment, on the other hand, should improve employees' learning hence innovation (Nonaka \& Takeuchi, 1995). McAdam, (2000) states that "knowledge embodiment can build on new knowledge construction and enable the process of innovation to be further incorporated within the organization".

Moreover, this study contributes to the literature in different ways. First, it asserts that OL assists in improving OI in manufacturing organization of developing countries. Second, it highlights the substantial benefits of applying KM, OL and OI in manufacturing companies in Jordan. Furthermore, it enhances the relationship between KM and innovativeness' literature by providing empirical evidence, suggesting that OL is as important as KM to advance organizational innovation. Most importantly, it identifies the problem of a developing economy which is not promoting OL or taking care of it as much as they attended to KM in their organizational practices.

\section{IMPLICATIONS}

This study presents theoretical and practical implications. The theoretical implication is taking part in the growing body of research by identifying organizational learning as a mediator between knowledge management and organizational innovation. To the knowledge of the author, this is the first study to empirically examine these interrelations in the economy of developing countries (i.e., Jordan). The study results may be an important tool for future researches as they can be the foundation for upcoming studies covering the topic of KM, OL, \& OI in developing countries.

Regarding the managerial implications of the research, managers ought to recognize that OL is equally important to KM. This entails that OL should be utilized within organizations to achieve OI and thus a competitive advantage for those who apply it. The problem of the surveyed organizations' managers is that they exert their effort to promote KM especially that part of adoption from best practice organizations without the proper adaptation of that knowledge which in turn results in an inefficient organizational learning environment. Moreover, managers ought to value their significance and encourage their employees to adopt knowledge from various sources; which, if implemented correctly, will enhance the OL environment. In other words, managers should recall (Senge, 1990, p. 7) indication concerning a learning organization "where people continually expand their capacity to create the results they truly desire, where new and expansive patterns of thinking are nurtured, where collective aspiration is set free, and where people are continually learning how to learn together".

\section{LIMITATIONS AND FURTHER RESEARCH}

This study has several limitations which may lay the foundation for future research. First, the study's sample was only tested on managers in surveyed organization leaving out employees. Hence, conducting a similar study that sheds light on employees may widen the results spectrum. Second, the study was undertaken in the context of a developing country (i.e., Jordan). Therefore, the results are of relatively accurate significance in developing countries but may ignore developed ones. Thus, researching both developed and underdeveloped organizations could make the current study's results more beneficial and further highlight the drawbacks of developing countries' organizations. Third, although the sample size may be referred to as acceptable, a wider sample may introduce a more advanced result analysis making the study's outcomes further punctual and applicable. Fourth, this study applies only four KM variables (i.e., creation, adoption, adaptation, and embodiment) in fact, KM disciplines consist of a plethora of dimensions (e.g., acquisition, conversion, application, donating, transfer ...etc.). Therefore, investigating all $\mathrm{KM}$ variables may result in robust identification of

developing countries. At last, the current study utilizes the snapshot research method. Thus, as KM is dynamic, longitudinal research highlighting that dynamism would be beneficial. 


\section{CONCLUSION}

The current study highlights the significance of knowledge management with organizational learning and organizational innovation. The study results were based on a sample of 457 managerial level respondents. To examine the research hypothesis, the researcher implemented structural equation modeling. Study results reveal a significantly positive relationship between both KM and organizational learning; and, KM and organizational innovation. Empirical results further indicate the existence of partial evidence to support the relationship between OL and OI. Hence, proper implementation of organizational learning by default indicates the necessity to implement KM leading to organizational innovation.

\section{REFERENCES}

Ahn, J. H., \& Chang, S. G. (2004). Assessing the contribution of knowledge to business performance: The KP33 Methodology. Decision Support Systems, 36(4), 403-416. https://doi.org/10.1016/S0167-9236(03)00029-0

Allameh, S. M., Rezaei, A., \& Bagheri, M. M. (2014). The mediating role of organizational learning between knowledge management success factors and organizational innovation: A conceptual framework. MAGNT Research Report, 2(2), 771-787. Retrieved from http://www.academia.edu/download/35853535/11. Oct84-2014.pdf

Andone, II (2009) Measuring the performance of corporate knowledge management system. Informatica Economica, 13(4), 24-31.

Attia, A., \& Essam Eldin, I. (2018). Organizational learning, knowledge management capability and supply chain management practices in the Saudi food industry. Journal of Knowledge Management, 22(6), 1217-1242. https://doi.org/10.1108/JKM-09-2017-0409

Awang, Z. (2015). SEM made simple: A gentle approach to learning Structural Equation Modelling. Selangor, Malaysia: MPWS Rich Publication.

Bagheri, R., Hamidizadeh, M., \& Sabbagh, P. (2015). The mediator role of KM process for creative organizational learning case study: Knowledge based companies. VINE, 45(3), 420-445.

https://doi.org/10.1108/VINE-06-2014-0039

Baker, W. E., \& Sinkula, J. M. (2002). Market orientation, learning orientation and product innovation: Delving into the organization's black box. Journal of Market-Focused Management, 5(1), 5-23. Kluwer Academic Publishers. https://doi.org/10.1023/A:1012543911149

Baron, R. M., \& Kenny, D. A. (1986). The moderator-mediator variable distinction in social psychological research: Conceptual, strategic, and statistical considerations. Journal of Personality and Social Psychology, 51 (6), 1173-1182. https://doi.org/10.1037/0022-3514.51.6.1173

Bashir, M., \& Farooq, R. (2019). The synergetic effect of knowledge management and business model innovation on firm competence: A systematic review. International Journal of Innovation Science, Preprint, https://doi.org/10.1108/IJIS-10-2018-0103

Baxter, D., Roy, R., Doultsinou, A., Gao, J., \& Kalta, M. (2009). A knowledge management framework to support product-service systems design. International Journal of Computer Integrated Manufacturing, 22(12), 1073 1088. https://doi.org/10.1080/09511920903207464

Bharadwaj, S. S., Chauhan, S., \& Raman, A. (2015). Impact of knowledge management capabilities on knowledge management effectiveness in Indian organizations. Vikalpa: The Journal for Decision Makers, 40(4), 421-434. https://doi.org/10.1177/0256090915613572

Birasnav, M., \& Rangnekar, S. (2010). Knowledge management structure and human capital development in Indian manufacturing industries. Business Process Management Journal, 16(1), 57-75. https://doi.org/10.1108/14637151011017949

Bose, R. (2004). Knowledge management metrics. Industrial Management \& Data Systems, 104(6), 457-468. https://doi.org/10.1108/02635570410543771 
Brockman, B. K., \& Morgan, R. M. (2003). The role of existing knowledge in new product innovativeness and performance. Decision Sciences, 34(2), 385-419. https://doi.org/10.1111/1540-5915.02326

Bryant, S. E. (2005). The impact of peer mentoring on organizational knowledge creation and sharing: An empirical study in a software firm. Group \& Organization Management, 30(3), 319-338. https://doi.org/10.1177/1059601103258439

Bukowitz, W. R., \& Williams, R. L. (1999). The knowledge management fieldbook. Upper Saddle River, NJ: Financial Times Prentice Hall.

Cantner, U., Joel, K., \& Schmidt, T. (2011). The effects of knowledge management on innovative success - An empirical analysis of German firms. Research Policy, 40(10), 1453-1462. https://doi.org/10.1016/j.respol.2011.06.007

Castaneda, D. I., Manrique, L. F., \& Cuellar, S. (2018). Is organizational learning being absorbed by knowledge management? A systematic review. Journal of Knowledge Management, 22(2), 299-325. https://doi.org/10.1108/JKM-01-2017-0041

Corfield, A., Paton, R., \& Little, S. (2013). Does knowledge management work in NGOs? A longitudinal study. International Journal of Public Administration, 36(3), 179-188. https://doi.org/10.1080/01900692.2012.749281

Crossan, M., Lane, H. W., \& White, R.E. (1999). An organizational learning framework: From intuition to institution. The Academy of Management Review, 24(3), 522- 337

Darroch, J. (2005). Knowledge management, innovation, and firm performance. Journal of Knowledge Management, 9(3), 101-115. https://doi.org/10.1108/13673270510602809

Darroch, J., \& McNaughton, R. (2003). Beyond market orientation: Knowledge management and the innovativeness of New Zealand firms. European Journal of Marketing, 37(3/4), 572-593. https://doi.org/10.1108/03090560310459096

Dimitriades, Z. S. (2005). Creating strategic capabilities: Organizational learning and knowledge management in the new economy. European Business Review, 17(4), 314-324. https://doi.org/10.1108/09555340510607361

Du Plessis, M. (2007). The role of knowledge management in innovation. Journal of Knowledge Management, 11(4), 20-29. https://doi.org/10.1108/13673270710762684

Dul, J., Ceylan, C., \& Jaspers, F. (2011). Knowledge workers' creativity and the role of the physical work environment. Human Resource Management, 50(6), 715-734. https://doi.org/10.1002/hrm.20454

Ferraris, A., Santoro, G., \& Dezi, L. (2017). How MNC's subsidiaries may improve their innovative performance? The role of external sources and knowledge management capabilities. Journal of Knowledge Management, 21(3), 540-552. https://doi.org/10.1108/JKM-09-2016-0411

Garvin, D. A., Edmondson, A. C., \& Gino, F. (2008). Is yours a learning organization? Harvard Business Review, 86(3), 109-116. Retrieved from https://www.alnap.org/system/files/content/resource/files/main/r0803hpdf-eng.pdf

Gloet, M., \& Terziovski, M. (2004). Exploring the relationship between knowledge management practices and innovation performance. Journal of Manufacturing Technology Management, 15(5), 402-409. https://doi.org/10.1108/17410380410540390

Goh, A. L. S. (2005). Harnessing knowledge for innovation: An integrated management framework. Journal of Knowledge Management, 9(4), 6-18. https://doi.org/10.1108/13673270510610297

González, L. M., Giachetti, R. E., \& Ramirez, G. (2005). Knowledge management-centric help desk: Specification and performance evaluation. Decision Support Systems, 40(2), 389-405. https://doi.org/10.1016/j.dss.2004.04.013

Hair, J. F. Jr, Black, W. C., Babin, B. J., \& Anderson, R. E. (2014). Multivariate data analysis (7th ed.). Essex, England: Pearson Education Limited. Retrieved from https://is.muni.cz/el/1423/podzim2017/PSY028/um/ Hair Multivariate data analysis 7 th revised.pdf 
Hsiao, H. C., Chang, J. C., \& Chen, S. C. (2014). The influence of support for innovation on organizational innovation: Taking organizational learning as a mediator. The Asia-Pacific Education Researcher, 23(3), 463472. https://doi.org/10.1108/JKM-01-2017-0041

Hsu, R. C., Lawson, D., \& Liang, T. P. (2007). Factors affecting knowledge management adoption of Taiwan small and medium-sized enterprises. International Journal of Management and Enterprise Development (IJMED), 4(1), 30-51. https://doi.org/10.1504/IJMED.2007.011454

Huang, M. J., Chen, M. Y., \& Yieh, K. (2007). Comparing with your main competitor: The single most important task of knowledge management performance measurement. Journal of Information Science, 33(4), 416-434. https://doi.org/10.1177/0165551506076217

Huber, G. P. (1991). Organizational learning: The contributing processes and the literatures. Orgnizational Science, 2(1), 88-115.

Hurley, R. F., \& Hult, G. T. M. (1998). Innovation, market orientation, and organizational learning: An integration and empirical examination. Journal of Marketing, 62(3), 42-54. https://doi.org/10.1177/002224299806200303

Imran, M. K., Ilyas, M., \& Fatima, T. (2017). Achieving organizational performance through knowledge management capabilities: Mediating role of organizational learning. Pakistan Journal of Commerce and Social Sciences, 11(1), 105-124. Retrieved from http://www.jespk.net/publications/341.pdf

Jain, A. K., \& Moreno, A. (2015). Organizational learning, knowledge management practices and firm's performance: An empirical study of a heavy engineering firm in India. The Learning Organization, 22(1), 14-39. https://doi.org/10.1108/TLO-05-2013-0024

Jerez-Gomez, P., Cespedes-Lorente, J., \& Valle-Cabrera, R. (2005). Organizational learning capability: A proposal of measurement. Journal of Business Research, 58(6), 715-725. https://doi.org/10.1016/j.jbusres.2003.11.002

Jiménez-Jiménez, D., \& Sanz-Valle, R. (2011). Innovation, organizational learning, and performance. Journal of Business Research, 64(4), 408-417. https://doi.org/10.1016/j.jbusres.2010.09.010

Ju, T. L., Li, C. Y., \& Lee, T. S. (2006). A contingency model for knowledge management capability and innovation. Industrial Management \& Data Systems, 106(6), 855-877. https://doi.org/10.1108/02635570610671524

Kalmuk, G., \& Acar, A. Z. (2015). The mediating role of organizational learning capability on the relationship between innovation and firm's performance: A conceptual framework. Procedia - Social and Behavioral Sciences, 210, 164-169. https://doi.org/10.1016/j.sbspro.2015.11.355

Karasneh, A. A. F. (2002). An integrated model of knowledge management systems. Doctoral Thesis. Exeter, UK: University of Exeter. Retrieved from https://ethos.bl.uk/OrderDetails.do?uin=uk.bl.ethos.246392

Karasneh, A. A. F., \& Al-kalili, S. (2009). Knowledge management components: Analytical study at Jordanian Ministry of Education. Jordan Journal of Business Administration, 5(3), 293-326. Retrieved from https://journals.ju.edu.jo/JJBA/article/view/362

Karasneh, A. A. F., \& Al-Zoubi, M. (2018). Factors affecting knowledge sharing in special education - A Jordanian study. Knowledge and Process Management, 26(1), 41-50. https://doi.org/10.1002/kpm.1588

Kiessling, T. S., Richey, R. G., Meng, J., \& Dabic, M. (2009). Exploring knowledge management to organizational performance outcomes in a transitional economy. Journal of World Business, 44(4), 421-433. https://doi.org/10.1016/j.jwb.2008.11.006

King, W. R. (2009). Knowledge management and organizational learning. In W. R. King (Ed.). Knowledge management and organizational learning (pp. 3-13). Annals of Information Systems (volume 4). Boston, MA: Springer. https://doi.org/10.1007/978-1-4419-0011-1_1

Kiziloglu, M. (2015). The effect of organizational learning on firm innovation capability: An investigation in the banking sector. Global Business and Management Research: An International Journal, 7(3), 17-33. Retrieved from https://pdfs.semanticscholar.org/2c4d/42bf879dfe989bb7e9e6490b08307d23e9df.pdf

Kuah CT, Wong KY and Wong WP (2012). Monte Carlo Data Envelopment Analysis with Genetic Algorithm for knowledge management performance measurement. Expert Systems with Applications 39(10): 9348-9358. 
Liao, S. H., \& Wu, C. C. (2010). System perspective of knowledge management, organizational learning, and organizational innovation. Expert Systems with Applications, 37(2), 1096-1103. https://doi.org/10.1016/j.eswa.2009.06.109

Lin, H. F., \& Lee, G. G. (2005). Impact of organizational learning and knowledge management factors on ebusiness adoption. Management Decision, 43(2), 171-188. https://doi.org/10.1108/00251740510581902

Liu, Y., Zhou, J., \& Gao, J. (2008, October). The impact of organizational learning on knowledge transfer and dynamic capabilities: An empirical study in Chinese high-tech industries. Proceedings of the 4th International Conference on Wireless Communications, Networking and Mobile Computing (pp. 1-4). Dalian, China: IEEE. https://doi.org/10.1109/WiCom.2008.2561

Lopez-Nicolas, C., \& Soto-Acosta, P. (2010). Analyzing ICT adoption and use effects on knowledge creation: An empirical investigation in SMEs. International Journal of Information Management, 30(6), 521-528. https://doi.org/10.1016/j.ijinfomgt.2010.03.004

McAdam, R. (2000). Knowledge management as a catalyst for innovation within organizations: A qualitative study. Knowledge and Process Management, 7(4), 233-241. https://doi.org/10.1002/1099_ 1441(200010/12)7:4<233::AID-KPM94>3.3.CO;2-6

Massa, S., \& Testa, S. (2004). Innovation or imitation? Benchmarking: A knowledge management process to innovate services. Benchmarking: An International Journal, 11(6), 610-620. https://doi.org/10.1108/14635770410566519

Ngah, R., Tai, T., \& Bontis, N. (2016). Knowledge management capabilities and organizational performance in Roads and Transport Authority of Dubai: The mediating role of learning organization. Knowledge and Process Management, 23(3), 184-193. https://doi.org/10.1002/kpm.1504

Nonaka, I., \& Takeuchi, H. (1995). The knowledge creating company: How Japanese companies create the dynamics of innovation. Oxford, UK: Oxford University Press. https://doi.org/10.1016/0024-6301(96)81509-3

Nonaka, I., Toyama, R., \& Konno, N. (2000). SECI, Ba and Leadership: A unified model of dynamic knowledge creation. Long Range Planning, 33(1), 5-34. https://doi.org/10.1016/S0024-6301(99)00115-6

Nonaka, I, \& Von Krogh, G. (2009). Tacit knowledge and knowledge conversion: Controversy and advancement in organizational knowledge creation theory. Organization Science, 20(3), 635-652. https://doi.org/10.1287/orsc. 1080.0412

Nouri, B. A., Ghorbani, R., \& Soltani, M. (2017). The effect of knowledge management on organizational innovation with the mediating role of organizational learning (case study: Agricultural Bank in Iran). Journal of Applied Economics and Business Research (JAEBR), 7(3), 194-211. Retrieved from http://www.aebrjournal.org/uploads/6/6/2/2/6622240/joaebrseptember2017 194 211.pdf

Palacios, D., Gil, I., \& Garrigos, F. (2009). The impact of knowledge management practices on innovation and entrepreneurship in the biotechnology and telecommunications industries. Small Business Economics, 32(3), 291-301. https://doi.org/10.1007/s11187-008-9146-6

Patton, M. Q. (2001). Use a criterion of quality in evaluation. Advances in Program Evaluation, 7 155-180.

Preacher, K. J., \& Hayes, A. F. (2008). Asymptotic and resampling strategies for assessing and comparing indirect effects in multiple mediator models. Behavior Research Methods, 40(3), 879-891. https://doi.org/10.3758/BRM.40.3.879

Raj, R., \& Srivastava, K. B. L. (2013). The mediating role of organizational learning on the relationship among organizational culture, HRM practices and innovativeness. Management and Labor Studies, 38(3), 201-223. https://doi.org/10.1177/0258042X13509738

Raj, R., \& Srivastava, K. B. L. (2016). The mediating role of organizational learning on the relationship between market orientation and innovativeness. The Learning Organization, 23(5), 370-384. https://doi.org/10.1108/TLO-09-2013-0051

Real, J. C., Roldán, J. L., \& Leal, A. (2014). From entrepreneurial orientation and learning orientation to business performance: Analyzing the mediating role of organizational learning and the moderating effects of organizational size. British Journal of Management, 25(2), 186-208. https://doi.org/10.1111/j.1467$\underline{8551.2012 .00848 . \mathrm{x}}$ 
Recker, J. (2011). Evaluations of process modeling grammars: Ontological, qualitative and quantitative analyses using the example of BPMN. Lecture Notes in Business Information Processing (volume 71). Heidelberg, Germany: Springer-Verlag. https://doi.org/10.1007/978-3-642-18360-7

Salehi, Y., \& Naseri, A. (2018). Investigate the relationship between organizational learning capabilities and organizational innovation in the food industry (subsidiary industrial estates of Kermanshah Province). International Journal of Information, Business and Management, 10(4), 222-237. Retrieved from https://search.proquest.com/openview/ccae84ed4fe7ac6c8e3ac7984f38cf34/1?pqorigsite $=$ gscholar $\& \mathrm{cbl}=2032142$

Senge, P. (1992). The fifth discipline: The art and practice of the learning organization. London, UK: Century Business.

Sobel, M. E. (1982). Asymptotic intervals for indirect effects in structural equations models. In S. Leinhart (Ed.). Sociological methodology (volume 13) (pp. 290-312). San Francisco, CA: Jossey-Bass. https://doi.org/10.2307/270723

Sørensen, J. B., \& Stuart, T. E. (2000). Aging, obsolescence, and organizational innovation. Administrative Science Quarterly, 45(1), 81-112. https://doi.org/10.2307/2666980

Stanovcic, T., Pekovic, S. \& Bouziri, A. (2015). The effect of knowledge management on environmental innovation: The empirical evidence from France. Baltic Journal of Management, 10(4), 413-431, https://doi.org/10.1108/BJM-01-2015-0012

Stata R. (1989). Organizational learning - The key to management innovation. MIT Sloan Manage Review, 30(3), 63-74. Retrieved from https://sloanreview.mit.edu/article/organizational-learning-the-key-tomanagement-innovation/

Svetina, A. C., \& Prodan, I. (2008). How internal and external sources of knowledge contribute to firms' innovation performance. Managing Global Transitions, 6(3), 277-299. Retrieved from http:// citeseerx.ist.psu.edu/viewdoc/download?doi=10.1.1.530.1400\&rep=rep1\&type=pdf

Tamer Cavusgil, S., Calantone, R., \& Zhao, Y. (2003). Tacit knowledge transfer and firm innovation capability. Journal of Business \& Industrial Marketing, 18(1), 6-21. https://doi.org/10.1108/08858620310458615

Therin, F. (2003, January). Organizational learning and innovation in high-tech small firms. Proceedings of the 36th Hawaii International Conference on System Sciences (HICSS 03) (pp. 1-8). Big Island, HI, USA: IEEE. https://doi.org/10.1109/HICSS.2003.1174262

Thomas, J. B., Sussman, S. W., \& Henderson, J. C. (2001). Understanding 'strategic learning': Linking organizational learning, knowledge management, and sensemaking. Organization Science, 12(3), 331-345. https://doi.org/10.1287/orsc.12.3.331.10105

Uotila, J. (2017). Exploratory and Exploitative Adaptation in Turbulent and Complex Landscapes, European Management Review, 15(4), 505-519. https://doi.org/10.1111/emre.12140

Vieira, D. (2013). Interorganizational learning in the Brazilian bioethanol industry. Proceedings of the International Scientific Conference on Management of Knowledge and Learning (pp. 889-896). Zadar, Croatia: ToKnowPress. Retrieved from https://pure.mpg.de/rest/items/item 2060331 1/component/file 2060330/content

Walczak, S. (2008). Knowledge management and organizational learning: An international research perspective. The Learning Organization, 15(6), 486-494. https://doi.org/10.1108/09696470810907392

Wang, C. L., \& Ahmed, P. K. (2004). The development and validation of the organizational innovativeness construct using confirmatory factor analysis. European Journal of Innovation Management, 7(4), 303-313. https://doi.org/10.1108/14601060410565056

Wang, X., \& Xu, M. (2018). Examining the linkage among open innovation, customer knowledge management and radical innovation: The multiple mediating effects of organizational learning ability. Baltic Journal of Management, 13(3), 368-389. https://doi.org/10.1108/BJM-04-2017-0108

Yang, J. T. (2007). The impact of knowledge sharing on organizational learning and effectiveness. Journal of Knowledge Management, 11 (2), 83-90. https://doi.org/10.1108/13673270710738933

Zack, M., McKeen, J., \& Singh, S. (2009). Knowledge management and organizational performance: An exploratory survey. Journal of Knowledge Management, 13(6), 392-409. https://doi.org/10.1108/13673270910997088 


\section{APPENDIX}

\begin{tabular}{|c|c|}
\hline \multicolumn{2}{|c|}{ Knowledge management, Organizational Learning and Organizational Innovation Measurement Scale } \\
\hline Constructs & Statements \\
\hline Knowledge creation & $\begin{array}{l}\text { My corporation }[\ldots] \\
\text { 1. encourages its employees to generate new ideas or methods. } \\
\text { 2. uses brainstorming and know-how of employees to generate novel ideas. } \\
\text { 3. 's work environment encourages creativity and innovation. } \\
\text { 4. has systems that capture its employees' knowledge. }\end{array}$ \\
\hline Knowledge adoption & $\begin{array}{l}\text { In my corporation, management }[\ldots] \\
\text { 1. encourages the adoption of external knowledge. } \\
\text { 2. has the ability to learn from external knowledge processes. } \\
\text { 3. invites external specialists to exchange their knowledge and experiences with its } \\
\text { employees. } \\
\text { 4. benefits from global best-practice knowledge and adopts it. }\end{array}$ \\
\hline Knowledge adaptation & $\begin{array}{l}\text { My corporation }[. . .] \\
\text { 1. adapts created or adopted knowledge to meet the requirements of their internal } \\
\text { context. } \\
\text { 2. exploits created knowledge and explores adopted knowledge. } \\
\text { 3. refines created or adopted knowledge to disseminate it among its employees. } \\
\text { 4. utilizes adapted knowledge innovatively to achieve a competitive advantage }\end{array}$ \\
\hline Knowledge embodiment & $\begin{array}{l}\text { My corporation }[\ldots] \\
\text { 1. documents its created and/or adopted knowledge to be put into real practice. } \\
\text { 2. puts organizational knowledge into a form that makes it accessible to those who } \\
\text { need it. } \\
\text { 3. stores specialists' knowledge as reference programs on databases. } \\
\text { 4. codifies new knowledge using databases, artificial intelligence, and information } \\
\text { systems. }\end{array}$ \\
\hline Organizational Learning & $\begin{array}{l}\text { My corporation }[\ldots] \\
\text { 1. has processes for incremental improvements to existing product, market or service. } \\
\text { 2. has processes for stimulus-response to react to discrete environmental changes. } \\
\text { 3. breaks routine behaviors and addresses problem directly } \\
\text { 4. actively responses to dramatically environmental changes } \\
\text { 5. has continuous experiment and feedback with examining the appropriateness of } \\
\text { current behavior }\end{array}$ \\
\hline Behaviour innovation & $\begin{array}{l}\text { 1. We get a lot of support from managers if we want to try new ways of doing } \\
\text { things. } \\
\text { 2. In our company, we tolerate individuals who do things in a different way. } \\
\text { 3. We are willing to try new ways of doing things and seek unusual, novel solutions. } \\
\text { 4. We encourage people to think and behave in original and novel ways. }\end{array}$ \\
\hline Product innovation & $\begin{array}{l}\text { 1. In new product and service introductions, our company is often first-to-market. } \\
\text { 2. Our new products and services are often perceived as very novel by customers. } \\
\text { 3. In comparison with our competitors, our company has introduced more innova- } \\
\text { tive products and services during the past five years. } \\
\text { 4. In comparison with our competitors, our company has a lower success rate in } \\
\text { new products and services launch. }\end{array}$ \\
\hline Process innovation & $\begin{array}{l}\text { 1. We are constantly improving our business processes. } \\
\text { 2. Our company changes production methods at a great speed in comparison with } \\
\text { our competitors. } \\
\text { 3. During the past five years, our company has developed many new management } \\
\text { approaches } \\
\text { 4. When we cannot solve a problem using conventional methods, we improvise on } \\
\text { new methods }\end{array}$ \\
\hline
\end{tabular}




\begin{tabular}{|c|c|}
\hline Market innovation & $\begin{array}{l}\text { 1. Our recent new products and services are only minor changes from our previous } \\
\text { products and services } \\
\text { 2. New products and services in our company often take us up against new com- } \\
\text { petitors } \\
\text { 3. In comparison with our competitors, our products' most recent marketing pro- } \\
\text { gram is revolutionary in the market. } \\
\text { 4. In new product and service introductions, our company is often at the cutting } \\
\text { edge of technology. }\end{array}$ \\
\hline Strategic innovation & $\begin{array}{l}\text { 1. Our firm's R\&D or product development resources are not adequate to handle } \\
\text { the development need of new products and services. } \\
\text { 2. Key executives of the firm are willing to take risks to seize and explore "chancy" } \\
\text { growth opportunities. } \\
\text { 3. Senior executives constantly seek unusual, novel solutions to problems via the } \\
\text { use of "idea men". } \\
\text { 4. When we see new ways of doing things, we are last at adopting them. }\end{array}$ \\
\hline
\end{tabular}

\section{BIOGRAPHY}

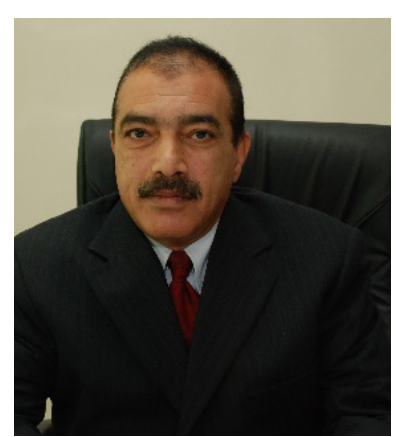

Abed Al-Fatah Karasneh is an Associate professor of Knowledge Management in the School of Business at Yarmouk University, Jordan. His teaching and research interest focus on knowledge management, creativity, innovation and organizational renewal. His current research interests include the measurement of knowledge management and focus on the developing economy. He believes that developing countries economy rely mainly on the ability of organizations to reinforce knowledge management and its antecedents as a strategic tool to a achieve a competitive advantage. 